\title{
Sustainable Innovation: Concepts and Challenges for Tourism Organizations
}

\author{
Mercedes Hernández Esquivel \\ Universidad Autónoma del Estado de México, Mexico \\ mhernandezeo17@alumno.uaemex.mx \\ Elva Esther Vargas Martínez \\ Universidad Autónoma del Estado de México, Mexico \\ eevargasm@uaemex.mx
}

Alejandro Delgado Cruz
Universidad Autónoma del Estado de México, Mexico
adelgadoc@uaemex.mx

Juan Manuel Montes Hincapié

Universidad de Medellin, Colombia

jmontes@udem.edu.co

Tourism companies are looking for new management strategies for helping to preserve their environment and generate positive effects in their social space. Sustainable innovation ( $\mathrm{sI}$ ) is the possibility that organizations must introduce changes, not only in products or services but also in their business model, to achieve a balance between economic, social, and environmental factors. The purpose of this article is to recognize the nature and scope of the existing literature in order to discover patterns of interpretation and lines of research, as well as to create a solid starting point for the academic and working community. We decided on a qualitative systematic review of articles identified in a scientific journal specializing in tourism, sustainability, and business management, using the classification contained in the Web of Science and Scopus databases. We filtered documents based on the criteria of relevance, considering the years from 2010 to 2020. This research includes five categories: business models oriented towards sustainable innovation, sustainable innovation: radical or incremental, dynamic capacities for sustainable innovation, role of stakeholders in sustainable innovation, and drivers of sustainable innovation.

Keywords: sustainable innovation, tourism organizations, sustainable business model

(cc)BY-SA $h$ https://doi.org/10.26493/2335-4194.14.175-187

\section{Introduction}

The crisis facing tourism due to the Covid-19 pandemic invites us to reflect on how this activity has been conducted (OECD, 2020b). Tourism has long been relevant for countries due to its main economic benefits; however, it should be recognized that it has generated negative impacts in social and environmental systems.

A more humane approach is required that pursues economic growth as well as human development and environmental conservation (United Nations, 2015). 
In this sense, it is necessary that organizations, as an important element of the tourism system, also contribute to the challenge of these changes by seeking new forms of management that will allow them to remain in the market (OECD, 2O2Oa).

Sustainable innovation (SI) is a recent academic topic still under construction, encompassing several meanings and conceptual approaches. There is still scarce literature regarding the relationship with tourism companies. Therefore, the main purpose of this article is to recognize the nature and scope of the existing literature to discover patterns of interpretation and lines of research, as well as to create a solid starting point for the academic and working community. We searched for a systematic review process in the databases Web of Science and Scopus, identifying that the studies are grouped into six categories that explain si from different perspectives.

Most of the studies are in one of the two variables that make up the binomial, either in innovation or sustainability, and those that manage to integrate them are oriented towards the environmental sphere of the latter. Likewise, the context of the study is mainly applied to lodging companies, with other types of organizations yet to be included. This way, our research contributes to a greater understanding of the subject, rescuing future lines of research to strengthen the development of the tourism sector.

The paper consists of a theoretical section that explains the object of study. This is followed by the methodology that describes the process. Next, the results are shown according to each category. Finally, the conclusions and future lines of research are presented.

\section{Sustainable Innovation: Theoretical Background}

Schumpeter (1934) is recognized as the main researcher who consolidated the study of innovation by moving away from the classical paradigm and introducing a dynamic analysis coming from industrial change, which he called 'circular flow.' To Schumpeter, economic growth becomes a process of evolution, which does not come from the effect of external factors such as politics or the consumer but has an internal origin through innovation. Scilicet, it arises from within the company, which can even educate the consumer - if necessary - creating the need to obtain a new product (Olaya Dávila, 2008).

The concept of innovation that Schumpeter (1934) contributed is based on industrial production, and therefore, related to the production of new goods or even the same goods, but with different methods. He details five categories: (a) the introduction of a new product, (b) the introduction of a new method of production, (c) the opening of a new market, (d) the conquest of a new source of supply of raw materials or manufactured products, and (e) the creation of a new organization of any industry (Zuñiga-Collazos et al., 2019). Following this line, the organization acquires the leading role in creating innovations, such as the role of the entrepreneur when achieving a new dimension in the function that is being performed; or the individual who performs new combinations by fulfilling the task of innovating, but not the place in the hierarchy held by the individual within the organization (Olaya Dávila, 2008).

Another element in Schumpeter's (1968) conceptual construction is the term 'creative destruction,' recognizing it as the fundamental impulse that puts and keeps the capitalist machine in motion, because profit resulting from successful innovations generates the creation of new companies, which in turn, also originate a complete reordering of the industry's structural framework. To this end, the organization plays a leading role and professionalizes research and development (R\&D) activities, which can be within the business unit or outside, through technological research centres or universities (Olaya Dávila, 2008). However, a new meaning has been found for the innovation concept from its social focus, developed during the seventies with greater precision (Hernández-Ascanio et al., 2016).

Social innovation stems from the need to achieve development with a more humanistic bent. Search is based on exploring and generating new ideas that help to achieve an inclusive society and a good quality of life. Opportunities revolve around education, health, employment, family, community life, gender equity, and environment, considering not only access to these but also quality (Quandt et al., 2017). These new practices to address social challenges have a positive influ- 
ence on individuals and organizations, gaining importance by transcending from the economic to the social value (Vega Jurado, 2017).

The European Commission (2013, p. 6) conceptualizes social innovation as 'the development and implementation of new ideas (products, services, and models) to satisfy social needs and create new social relationships or collaborations. It represents new answers to social demands that affect the process of social interactions, oriented to improve human well-being.' The main goal is to find answers to social problems by identifying and delivering new services that improve the quality of life of individuals and communities (OECD, 2011). Social innovation is not exclusive to a specific economic sector. In public organizations, it acquires importance for the development of public policy, attending to social needs and helping to generate more innovative and efficient environments for those that already exist, even to encourage the productive sector (Alonso-Martinez et al., 2015).

In business, this means more than quality products and reliable services. It requires organizations to contribute positively to improve the conditions of society by returning part of the economic benefit, and having an ethical, collaborative, and socially responsible behaviour (Hernández-Ascanio et al., 2016). In this sense, the company plays a fundamental role as a generator of social change, and although this is not its main goal, it can be motivated to acquire visibility in the market, as well as a response to generating new business models oriented to get economic value and satisfaction of needs (Alonso-Martinez et al., 2019; Boons \& Lüdeke-Freund, 2013).

In environmental terms, innovation is found in several concepts such as eco-innovation, environmental innovation, ecological innovation, and green innovation. These terms are used interchangeably and were born as a response to the complex environmental situation experienced worldwide. Their indicators are related to forest destruction, depletion and pollution of water resources, loss of biodiversity, or impact by global warming (Velázquez Castro \& Vargas Martínez, 2014).

Because of this, the concept of eco-innovation acquired visibility, in economic policies and the business world, being considered as an important strategy to reduce environmental impacts generated by various economic activities. The OECD (2009, p. 13) points out that it is the creation of new or significantly improved products (goods or services), processes, marketing methods, organizational structures, or institutional arrangements, which (intentionally or not) produce environmental improvements.

For Carrillo-Hermosilla et al. (2010), eco-innovation is intended to improve environmental performance and as a side effect, could also reduce production costs. It can also be developed by external factors such as regulatory pressures and the market, or by internal factors such as efficiency, environmental culture, adoption of certifications, and business performance (Bonzanini Bossle et al., 2016).

Specifically, eco-innovation is interpreted as any type of innovation that is oriented towards sustainable development and economic progress, through the responsible and efficient use of natural resources, which ultimately allow a balance between business and nature (Peiró-Signes et al., 2011). Although the terms eco-innovation and SI are often used synonymously, the former refers to the environmental and economic dimension, while the latter is a broader definition that integrates ethical and social aspects (Kneipp et al., 2019).

SI, as an object of study, is still in an incipient stage and is supported by different disciplines for its theoretical-conceptual construct (Ratten et al., 2020). It combines two opposing terms, the conception of innovation which is related to change, destruction, or transformation, and on the other hand, sustainability which leads to the notion of preservation (Alderin \& Do, 2016). Under this understanding, their union implies the development of innovations in all spheres of life and its environment.

Thus, si suggests that innovation processes are no longer only related to economic objectives but also to environmental and social ones (Boons \& LüdekeFreund, 2013; Cillo et al., 2019; Kneipp et al., 2019). For Szekely and Strebel (2013), SI is the creation of something new that improves performance in all three dimensions of sustainability, and it is not limited to technological changes. It also includes changes in pro- 
cesses, operating practices, business models, thinking, and organizational systems. This implies that organizations improve social and ecological externalities while remaining financially viable (Dyck \& Silvestre, 2018).

It could be summarized that $\mathrm{sI}$ in companies is the synergic and inseparable integration of the economic, social and environmental, which allows reaching objectives related to sustainable development while remaining competitive and financially profitable (Dyck \& Silvestre, 2018). However, even though there is great awareness, companies are still reluctant regarding its implementation, considering it more expensive than conventional innovation since it requires high investments in technology, generating uncertainty and ignorance of the needs of the future market. Therefore, faced with this situation, the role of companies is to break with old paradigms and face new and more complex methods (Alderin \& Do, 2016).

Therefore, si offers companies the possibility of transforming themselves and aligning their operations with the objectives of sustainability under a precise observation of multiple factors, both internal and external, that allow the reduction of uncertainty and differentiate between good sustainability practices and products that are disseminated as sustainable. Up until now, there has still been insufficient demand, lack of dissemination, and little market adaptation (Fichter \& Clausen, 2016).

\section{Methodology}

Although there are several methodologies for literature review, we opted for the qualitative systematic review, which allows the identification, selection, and evaluation of relevant research on an object of study (Paré \& Kitsiou, 2017). It differs from other methodologies by developing a protocol in stages or phases for each of the activities carried out. Additionally, a description of the studies is added to discover patterns, barriers, and trends from the perspective and interpretation of the authors (Sobrido \& Rumbo-Prieto, 2018; Templier \& Paré, 2015).

Initially, we defined the research question: What is the nature and scope of the existing literature on sustainable innovation in tourism? The second stage con- sidered the literature search based on inclusion and exclusion criteria, including articles with the following features: (a) thematic coverage, obtaining the most comprehensive review possible through the important scientific journals; (b) representativeness in the field of tourism business knowledge; and (c) the period of publication from 2010 to 2020 , revealing the most recent knowledge, trends, or new patterns of interpretation. As exclusion criteria, we discarded editorials, prefaces, and book reviews.

A document search was performed using keywords in English, although it included articles in Spanish, considering 'sustainable innovation' as the main keywords and 'tourism,' 'tourism organization,' and 'sustainable business model' as secondary keywords. The databases with the greatest concentration of documents related to the object of study were Web of Science and Scopus. We considered their importance at an international level and their rigorous evaluation criteria.

For the third stage of evaluation and selection, we eliminated repeated articles. Then, through the review of the abstracts, we determined their relevance, separating those that were not related to the business sector and that did not contribute to the knowledge of the object of study. Finally, the full text was reviewed, including articles from bibliographic references, leaving a total of 63 documents (Figure 1).

In the last phase, we extracted data and prepared a bibliographic matrix for its classification. After analysing the documents, we defined five categories: (a) business models oriented towards sustainable innovation, (b) sustainable innovation: radical or incremental, (c) dynamic capacities of sustainable innovation, $(\mathrm{d})$ role of stakeholders in SI, and (e) drivers of sustainable innovation (Table 1).

\section{Results}

Business Models Oriented towards Sustainable Innovation

This topic is the most recurrent in si research. The content of this topic considers the customer as a core aspect of business models, management methods, and value proposition (Teece, 2010). Following this line, some authors emphasize that conventional business 


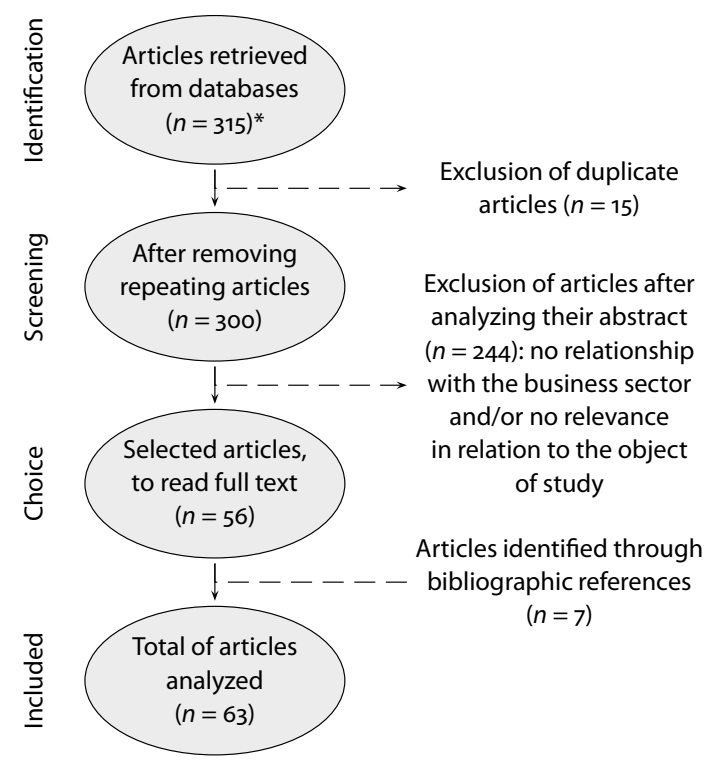

Figure 1 Flow Diagram of the Literature Review $\left({ }^{\star} 210\right.$ articles from the Web of Science and 105 articles from Scopus)

Table 1 Articles Classified by Category

\begin{tabular}{lcr}
\hline Category & Frequency & Percentage \\
\hline $\begin{array}{l}\text { Business models oriented to- } \\
\text { wards sustainable innovation }\end{array}$ & 11 & 17.5 \\
$\begin{array}{l}\text { Sustainable innovation: radical } \\
\text { or incremental? }\end{array}$ & 7 & 11.1 \\
$\begin{array}{l}\text { Dynamic capacities of sustainable } \\
\text { innovation }\end{array}$ & 15 & 23.8 \\
$\begin{array}{l}\text { Role of stakeholders in sustain- } \\
\text { able innovation }\end{array}$ & 10 & 15.9 \\
$\begin{array}{l}\text { Drivers of sustainable innovation } \\
\text { Total }\end{array}$ & 20 & 31.7 \\
\hline
\end{tabular}

models characterized by the appropriation of organizational value, maximize unidirectional dimensional profits, without considering their externalities in social and ecological contexts (Schaltegger et al., 2015). Nevertheless, the company currently seeks to create competitive advantages by moving towards more dynamic and sustainable business models, using innovation to develop integrated solutions that radically reduce the negative effects on nature and generate posi- tive effects on society (Geissdoerfer et al., 2018; Bocken et al., 2014; Bolton \& Hannon, 2016).

Likewise, literature shows that business models can be redesigned under strategies that allow the generation of value through sustainability (Yang et al., 2017; Boons \& Lüdeke-Freund, 2013). León-Bravo et al. (2019) propose two approaches: the first one suggests an evolutionary change where personnel, production processes, and technologies must be reinvented to integrate more sustainable products. The second suggests a retro-innovation rediscovery of traditional processes and values of environmental and social conservation. Thereby, the value proposal, the supply chain, the communication with the client, and the financial scheme become important when they are aligned with the sustainability spheres (Ratten et al., 2020; Rotondo et al., 2019).

Other studies recognize that sI is based on organizational culture, where companies make substantial transformations in line with their philosophy to better manage and evaluate their business model from a perspective based on the triple bottom line: cost reduction, sustainability, and competitiveness (Adams et al., 2016).

In the field of tourism, airlines were among the first companies to implement the concept of a sustainable business model by reducing the emissions of gases and noise that they emit into the environment. On the social side, they considered job satisfaction, which contributed to customer satisfaction resulting in increasing profits (Rotondo et al., 2019). However, not all sustainable business models manage to be successful. Some studies point out that most sustainable innovations do not prosper until they are tested in the market. It is at this point when companies decide to take them up again and apply them in organizations (Rotondo et al., 2019).

\section{Sustainable Innovation: Radical or Incremental?}

Research shows a dispute whether si should be incremental or radical. In the face of this argument, it is stated that most sustainable innovations made by companies are incremental because there is still not a large market for sustainable products and services (Kneipp et al., 2019). 
It is also considered that organizations can develop si through radical or incremental changes since both types of innovation contribute to sustainability and can lead to a long-term competitive advantage. In this sense, incremental changes allow the company to make gradual adjustments to existing activities and, with radical innovation, a new way of planning and managing strategies for the creation and capture of value is introduced, either to face a new challenge or to address an economic, social and environmental problem (Inigo et al., 2017).

Conversely, it is argued that incremental innovation is not sufficient to achieve the demanding goals of sustainability (climate change, biodiversity loss, poverty, to name a few). Rather, a radical change of an entire system is required (Carrillo-Hermosilla et al., 2010; Kennedy et al., 2017). Since radical innovation for sustainability can alter both production and consumption practices, achieving a substantial change in the market will impact natural and social preservation (Boons et al., 2013; Kuokkanen et al., 2018). In addition, its destructive characteristic of obsolete skills can contribute to the decline of traditional methods. So, with radical innovations, it is more likely to achieve an optimal configuration of the global system but one needs to consider that it represents great challenges (Wagner, 2012). In other words, although si allows incremental changes to be made to favour sustainability in organizations, a true transformation would imply rethinking incremental innovations.

\section{Dynamic Capacities of Sustainable Innovation}

Studies show that sis are dynamic organizational capabilities. This approach explains the ability of companies to restructure their internal and external resources and skills and in this way be able to quickly respond to changes in the environment (Teece, 2012; 2018). Miranda Torrez (2015) states that these strategic changes lead organizations to reach high levels of sustainable performance, even reaching proactive levels when competitive advantages are generated, forcing competitors to innovate sustainably. Other authors point out that the relationship between dynamic capacities and organizational routines influence innovation directly, achieving a greater degree of sustainabil- ity in tourism companies (Pace, 2016). This requires the identification and evaluation of knowledge opportunities, innovative technologies, and market solutions, which allow the mobilization of resources and skills to gain value in sustainability (Mousavi et al., 2018).

Along this line, dynamic capacities based on knowledge become relevant for the development of sustainable innovations, when the company orients its activities and processes to generate new knowledge and capacities and integrates external knowledge coming from the interested parties. This way, the collaborative practices of external knowledge with internal knowledge are fundamental for understanding the flows of new knowledge creation and innovation processes (Maines et al., 2019). Velázquez Castro and Vargas Martínez (2015) mention the importance of technological surveillance as one of the processes that convey information and knowledge to the tourism company, achieving innovations that contribute to sustainable business competitiveness through the connection of four functions: (a) surveillance, (b) plan and enable, (c) implement, and (d) verify and evaluate.

Some empirical studies, based on the dynamic capabilities, point out that each of them is integrated with elements or 'micro-foundations' that achieve sI. The elements that acquire bigger importance are the company's value propositions, outlining a business model that integrates ecological, economic, and social dimensions, and the coordination of a business ecosystem (Mousavi et al., 2019).

Shang et al. (2019, p. 3) introduced the concept of sustainable dynamic capacity, defining it as 'a corporation's ability to address rapidly evolving stakeholder expectations regarding sustainability. This implies modifying the company's functional capabilities in pursuit of economic, environmental, and social competence. Research on dynamic capabilities and sI has regularly focused on the industrial sector, showing that research on services in tourism is particularly incipient (Bartocci Liboni et al., 2017). Authors such as Krizaj et al. (2012) and Delgado Cruz et al. (2016), consider that innovations in the tourism sector cannot be evaluated in the same way as in industry due to the nature of the services, observing that tourism com- 
panies regularly resort to basic innovations (products, processes, and marketing), when they should innovate in business models to remain competitive and, above all, sustainable.

Studies of sI in tourism, particularly tourism companies, are regularly analysed from the perspective of their social, environmental and economic fields, and the most recurrent ones address issues related to products, processes, management, and marketing innovation, as well as institutional and technological innovations, there being a close interaction among the different categories (Hjalager, 2010). Likewise, organizational innovation, innovation strategies, technological innovation, knowledge management in innovation, and innovation models are analysed. Several of these topics are linked to pro-environmental actions that aim to create competitive advantages (Delgado Cruz et al., 2016). Also, the organizational structure, human capital, and collaboration networks are determinants for the development of the innovation capacity in companies (Delgado Cruz et al., 2018).

A study applied to the hotel sector found a link between the social relations of managers, knowledge, and the generation of dynamic capabilities for SI. These relations favoured the ability of companies to alter their resource base, improving access to information and knowledge to identify changes and allowing the company to adjust to environmental and social needs (Nieves, 2014).

\section{Role of Stakeholders in Sustainable Innovation}

The literature review provides evidence that addresses the role of stakeholders in the development of SI. SI is a complex process, that individual work alone could not trigger. So, the relationships and demands exerted by stakeholders (internal and external) can become the origin of social and environmental innovations (Alonso-Martinez et al., 2019; Ayuso et al., 2011; Juntunen et al., 2018; Rotondo et al., 2019; Schaltegger \& Wagner, 2011).

Primary stakeholders (such as employees and customers) are those that have become more important for research purposes. However, some authors considerer that si secondary stakeholders (e.g. NGOs, government, communities, universities) may be more rel- evant, as they are an important source for knowledge generation (Goodman et al., 2017). In contrast, there is evidence that the incorporation of secondary stakeholders does not support the momentum of si. Instead of looking for many actors, attention should be paid to choosing the right type of parties, and the right time for their integration into the innovation process (Juntunen et al., 2018; Driessen \& Hillebrand, 2012).

Goodman et al. (2017) analysed three roles that stakeholders play in contributing to SI, and depending on their actions, they may be proactive, reactive, or mixed. The first is when stakeholders stimulate or generate the idea of innovation while promoting greater use of the product. The reactive role is obtained when experience and feedback are provided to make the product more attractive, when assistance is given to build credibility and trust, educating the public on social and environmental issues related to innovation. Finally, the mixed roles are achieved when enabling collaboration among stakeholders or participating in the reconstruction of policies that allow innovation to flow.

The relationship with stakeholders poses new challenges when trying to reconcile the different interests, characteristics, and objectives pursued by each of them (Ferrero-Ferrero et al., 2018; Kazadi et al., 2016). Because of this, it is suggested that companies develop internal capacities that facilitate their integration and commitment, promoting greater innovation and balance among social, economic, and environmental aspects (Rhodes et al., 2014), as well as the integration of a good team of stakeholders (Bal et al., 2013).

\section{Drivers of Sustainable Innovation}

Another group of studies refers to the drivers of Is, which can improve the performance and innovation capacity of companies. In this sense, innovations regularly arise from qualified and motivated employees, research, and development processes (R\&D) (Ketata et al., 2015). There are influential external factors that put pressure on stakeholders to demand products produced under sustainable processes, such as regulatory government policies or financial support provided for their development (Ketata et al., 2015; Pellegrini et al., 2019; Sirirat \& Lamin, 2019). 
A line of empirical studies analyses the capacity for SI with a strategic orientation. This orientation is offered in three areas: (a) customer, (b) competition, and (c) technology. The role that consumers play in affecting the capacity of sI is of utmost importance, as they use their added value as a lever to improve the environmental innovation capacity of their companies (Tseng et al., 2019). Technologies are extremely important in the environmental sphere of tourism enterprises, innovating in energy efficiency, water use care, and waste management, among others, seen as an essential part of the sustainability strategy in the hotel industry (Chan et al., 2020).

Along the same lines, theoretical models associated with innovation, environmental marketing strategy, and the organizational environment are developed for the growth of sustainable innovations in hotels, finding that there is a close relationship among them. Thus, the business's reputation can be strengthened through its environmental marketing strategy. However, this is suggested not to consider the preference of customers as the only reason for adopting sustainable initiatives, but to understand the holistic benefits that are generated in the long term (Horng et al., 2017).

Research has shown that hotels are reluctant to adopt environmental technologies, even though they can reduce their operating costs, improve their image and contribute to the sustainable development of tourism. Chan et al. (2020) identified seven barriers: (a) environmental viability in terms of feasibility and costs; (b) lack of knowledge and uncertainty about the benefits of green technologies; (c) monopolized after-sales service due to high maintenance costs; (d) government and initial support for the adoption of environmental technologies; (e) customer experience in choosing to purchase; (f) shortage of skilled labour; and (g) finance. Simultaneously, other studies address the drivers of si in hosting companies and airlines, identifying regulatory compliance and brand positioning as ways to implement innovations around the preservation of natural resources (Dibra, 2015; Horng et al., 2017; Mousavi et al., 2018).

SI is largely related to entrepreneurship, since entrepreneurs are corporate leaders who see the opportunities in sustainability, and thus contribute to solv- ing complex social and ecological problems, which in turn act as a catalyst for transformation (DiVito \& Ingen-Housz, 2019). In the social sphere, research on innovation drivers in tourism highlights the entrepreneurial nature of creating job opportunities (Alegre \& Berbegal-Mirabent, 2016), ethical behaviour (Vargas Martínez et al., 2018), and the participation of communities as a key agent for the development of tourism destinations and their quality of life (Maleka \& Costa, 2014). Also, the network collaboration for the sustainability of large and small businesses is analysed, achieving an improvement in the quality of life of communities (Carlisle et al., 2013).

si maintains a relationship with the size of the company; large companies, technologically sophisticated, with innovative characteristics, and with international operations, generally include sustainability in the innovation of their products and processes. In addition, they make social investments focused on food, training, and assistance for the family, while investments of an environmental nature are oriented to the reduction of environmental impacts, decontamination programmes and projects, environmental audits, and certifications. However, these are not reasons that motivate them to innovate, such as economic objectives and market position (Gomes et al., 2011).

Other studies recognize that a company's ability to implement si depends on its financial situation and its willingness to change. Large companies generally have the resources to act, helping their global competitiveness, while small companies lack financial resources to be sustainable, although, if they are innovative, they will seek options to overcome economic obstacles in other ways (Ratten et al., 2020). In a significant relationship between SI and the success of an organization, empirical studies show that the adoption of sI practices is associated with business performance, contributing to superior corporate behaviour, as well as generating competitive advantages in the social sphere (Maier et al., 2019; Kneipp et al., 2019).

On the other hand, the implementation of inclusion strategies within government sectors for planning or financial support encourages companies to develop sustainable products and services (Davies \& Mullin, 2010). Some companies implement si to reduce pro- 
duction costs, resource optimization, and process efficiency, thus increasing profitability and environmental benefits (Van, 2019; Vinci et al., 2019); governance strategies are also being led to promote innovations in all areas (Lupova \& Dotti 2019).

For Vos et al. (2018), companies can perform better in si through organizational learning; since it allows them to recognize the value of new information, assimilating and applying it in such a way that knowledge will allow companies to adapt to the heterogeneous needs of the client and at the same time, mitigate the ecological and social impact.

\section{Conclusions and Further Research}

A big part of the research on SI is associated with factors that impel it from the inside and outside of the company. When a company develops is, usually the results coincide with economic aspects, acquiring economic value or profitability, derived from the sale of products as well as cost reduction. Another factor is the constant search for customer satisfaction around sustainable products. Similarly, the size of the company is influential, since large companies regularly have financial capabilities that allow them to innovate sustainably to develop competitive advantages and achieve market position (Ratten et al., 2020).

It is important to note that most studies have focused on industrial companies, so studies of the service sector have not acquired relevance, specifically those of the tourism sector (Bartocci Liboni et al., 2017; Hjalager, 2010). Therefore, as it is an incipient field of study, it is necessary to develop future research that will allow tourism companies to identify opportunities through which they can contribute significantly to environmental care and the development of a better society in the destinations where they are settled (Delgado Cruz et al., 2016).

The innovation diffusion theory has been used as a way of propagating $\mathrm{SI}$ in the tourism enterprise, since it consists of evaluating an innovation in order to adopt or reject it (Dibra, 2015), which facilitates its implementation due to the nature of the service it offers.

Empirical studies show that the general behaviour of tourism enterprises is unsustainable because tour- ism business management is dominated by short-term economic objectives, which implies a great concern that leads to the need to investigate proactive change in practices to contribute to sustainable tourism development (Velázquez Castro \& Vargas Martínez, 2015). si has not yet been able to fully integrate itself into the studies of tourism businesses. There is much research performed on innovation in each of its spheres (environmental, social, economic) but separately. It also shows that, within these business innovation capacities, it has not been developed as industry has.

Social and environmental problems are setting the tone to rethink tourism practice and its management. It is necessary to understand that true tourism development is not only economic but also social and ecological. Enterprise, as part of the tourism system, plays a fundamental role as a promoter of change. si represents the opportunity to reinvent itself and face the challenge of generating more complex organizational structures, with greater knowledge and learning than conventional business models.

Thus, this research acquires relevance by introducing contributions around the tourism sector, since the knowledge gap is wide and the field of tourism needs to be strengthened. si studies associated with the participation of stakeholders in the creation of new environmental and social values and practices are needed. On the other hand, research shows that large companies are more likely to develop is, motivated by the search for competitiveness, market positioning, and cost reduction. Meanwhile, small and medium enterprises are reluctant; the challenge is to strengthen these companies in the development of their innovation capabilities.

Another line of research is related to the management of internal and external knowledge and the influence that si has on the ability of organizations to become intelligent since one is not only intelligent for possessing advanced technology but also for taking care of the environment and contributing to a better social lifestyle. This could include studies that guide the handling of information and the performance of internal collaborators once the organizations have acquired the interest to innovate sustainably. One more line of research would be linked to dynamic capacities 
as a mechanism for tourism companies to identify the opportunities offered by the environment and to trigger a greater propensity towards SI.

In the public sector, sI is fundamental for the implementation of successful policies and projects, and for generating conditions that encourage tourism companies to develop sustainable innovations, which could lead to better development of tourism destinations and host communities. Finally, it is recognized that this study has certain limitations because it only explores scientific articles and does not consider other important sources of information such as patents, manuals of international organizations, and information from innovative institutions, that could be enriching for a broader understanding of the object of study.

\section{References}

Adams, R., Jeanrenaud, S., Bessant, J., Denyer, D., \& Overy, P. (2016). Sustainability-oriented innovation: A systematic review. International Journal of Management Reviews, 18(2), 180-205.

Alderin, C., \& Do, T. (2016). Sustainable innovation - Driving factors in large firms [Unpublished master's thesis]. Upsala University.

Alegre, I., \& Berbegal-Mirabent, J. (2016). Social innovation success factors: Hospitality and tourism social enterprises. International Journal of Contemporary Hospitality Management, 28(6), 1155-1176.

Alonso-Martinez, D., González-Álvarez, N., \& Nieto, M. (2015). La innovación social como motor de creación de empresas. Universia Business Review, 47, 48-63.

Alonso-Martinez, D., González-Álvarez, N., \& Nieto, M. (2019). The influence of financial performance on corporate social innovation. Corporate Social Responsibility and Environmental Management, 26(4), 859-871.

Ayuso, S., Ángel Rodríguez, M., García-Castro, R., \& Ángel Ariño, M. (2011). Does stakeholder engagement promote sustainable innovation orientation? Industrial Management \& Data Systems, 111(9), 1399-1417.

Bal, M., Bryde, D., Fearon, D., \& Ochieng, E. (2013). Stakeholder engagement: Achieving sustainability in the construction sector. Sustainability, 6(2), 696-710.

Bartocci Liboni, L. A., Chiappetta Jabbour, C. J., Lopes de Sousa Jabbour, A. B., \& Dvika, K. (2017). Sustainability as a dynamic organizational capability: A systematic review and a future agenda toward a sustainable transition. Journal of Cleaner Production, 142, 306-322.

Bocken, N. M. P., Short, S. W., Rana, P., \& Evans, S. (2014).
A literature and practice review to develop sustainable business model archetypes. Journal of Cleaner Production, 65, 42-56.

Bolton, R., \& Hannon, M. (2016). Governing sustainability transitions through business model innovation: towards a system understanding. Research Policy, 45(9), 1731-1742.

Boons, F., \& Lüdeke-Freund, F. (2013). Business models for sustainable innovation: state-of-the-art and steps towards a research agenda. Journal of Cleaner Production, 45, 9-19.

Boons, F., Montalvo, C., Quist, J., \& Wagner, M. (2013). Sustainable innovation, business models and economic performance: An overview. Journal of Cleaner Production, 45, $1-8$.

Bonzanini Bossle, M., Dutra de Barcellos, M., Marques, L., \& Sauvée, L. (2016). The drivers for adoption of ecoinnovation. Journal of Cleaner Production, 113(1), 861872.

Carlisle, S., Kunc, M., Jones, E., \& Tiffin, S. (2013). Supporting innovation for tourism development through multi-stakeholder approaches: Experiences from Africa. Tourism Management, 35, 59-69.

Carrillo-Hermosilla, J., Del Río, P., \& Könnölä, (2010). Diversity of eco-innovations: Reflections from selected case studies. Journal of Cleaner Production, 18(10-11), 1073-1083.

Chan, E. S. W., Okumus, F., \& Chan, W. (2020). What hinders hotels' adoption of environmental technologies: A quantitative study. International Journal of Hospitality Management, 84, 102324. https://doi.org/10.1016/j.ijhm.2019 .102324

Cillo, V., Petruzzelli, A. M., Ardito, L., \& Del Giudice, M. (2019). Understanding sustainable innovation: A systematic literature review. Corporate Social Responsibility and Environmental Management, 26(5), 1012-1025.

Davies, A., \& Mullin, S. (2010). Greening the economy: interrogating sustainability innovations beyond the mainstream. Journal of Economic Geography, 11(5), 793-816.

Delgado Cruz, A., Vargas Martinez, E. E., Montes Hincapié, J. M., \& Rodríguez Torres, F. (2016). Innovation in tourism companies, where are they and where are they going? An approach to the state of knowledge. Intangible Capital, 12(4), 1088-1155.

Delgado Cruz, A., Vargas Martinez, E. E., Rodríguez Torres, F., \& Montes Hincapié, J. M. (2018). Estructura organizacional, capital humano y redes de colaboración: Determinantes de la capacidad de innovación en restaurantes. AD-Minister, 32, 5-28. 
Dibra, M. (2015). Rogers theory on diffusion of innovation - The most appropriate theoretical model in the study of factors influencing the integration of sustainability in tourism businesses. Procedia: Social and Behavioral Sciences, 195, 1453-1462.

DiVito, L., \& Ingen-Housz, Z. (2019). From individual sustainability orientations to collective sustainability innovation and sustainable entrepreneurial ecosystems. Small Business Economics, 56, 1057-1072.

Driessen, P. H., \& Hillebrand, B. (2012). Integrating multiple stakeholder issues in new product development: An exploration. Journal of Product Innovation Management, 30(2), 364-379.

Dyck, B., \& Silvestre, B. (2018). Enhancing socio-ecological value creation through sustainable innovation 2.0: Moving away from maximizing financial value capture. Journal of Cleaner Production, 171, 1593-1604.

European Commission. (2013). Guide to social innovation.

Ferrero-Ferrero, I., Fernández-Izquierdo, M. Á., Muñ̃ozTorres, M. J., \& Bellés-Colomer, L. (2018). Stakeholder engagement in sustainability reporting in higher education: An analysis of key internal stakeholders' expectations. International Journal of Sustainability in Higher Education, 19(2), 313-336.

Fichter, K., \& Clausen, J. (2016). Diffusion dynamics of sustainable innovation-insights on diffusion patterns based on the analysis of 100 sustainable product and service innovation. Journal of innovation Management, 4(2), 30-37.

Geissdoerfer, M., Vladimirova, D., \& Evans, S. (2018). Sustainable business model innovation: A review. Journal of Cleaner Production, 198, 401-416.

Gomes, C. M., Kruglianskas, I., \& Scherer, F. L. (2011). Innovation management for sustainable development practices in the internalization context. Journal of Technology Management \& Innovation, 6(2), 111-127.

Goodman, J., Korsunova, A., \& Halme, M. (2017). Our collaborative future: Activities and roles of stakeholders in sustainability-oriented innovation. Business Strategy and the Environment, 26(6), 731-753.

Hernández-Ascanio, J., Tirado-Valencia, P., \& Ariza-Montes, A. (2016). El concepto de la innovación social: ámbitos, definiciones y alcances teóricos. CIRIEC-España, Revista de Economía Pública, Social y Cooperativa, 88, 165-199.

Hjalager, A. M. (2010). A review of innovation research in tourism. Tourism Management, 31(1), 1-12.

Horng, J. S., Liu, C. H., Chou, S. F., Tsai C. Y., \& Chung, Y. C. (2017). From innovation to sustainability: Sustainability innovations of ecofriendly hotels in Taiwan. Journal of Hospitality Management, 63, 44-52.
Inigo, E. A., Albareda, L., \& Ritala, P. (2017). Business model innovation for sustainability: Exploring evolutionary and radical approaches through dynamic capabilities. Industry and Innovation, 24(5), 512-542.

Juntunen, J. K., Halme, M., Korsunova, A., \& Rajala, R. (2018). Strategies for integrating stakeholders into sustainability innovation: A configurational perspective. Journal of Product Innovation Management, 36(3), 331355.

Kazadi, K., Lievens, A., \& Mahr, D. (2016). Stakeholder cocreation during the innovation process: Identifying capabilities for knowledge creation among multiple stakeholders. Journal of Business Research, 69(2), 525-540.

Kennedy, S., Whiteman, G., \& Van den Ende, J. (2017). Radical innovation for sustainability: The power of strategy and open innovation. Long Range Planning, 50(6), 712725.

Ketata, I., Sofka, W., \& Grimpe, C. (2015). The role of internal capabilities and firms' environment for sustainable innovation: Evidence for Germany. R\&D Management, 45(1), $60-75$.

Kneipp, J., Gomes, C., Bichueti, R., Frizzo, K., \& Perlin, A. P. (2019). Sustainable innovation practices and their relationship with the performance of industrial companies. Revista de Gestao, 26(2), 94-111.

Krizaj, D., Brodnik, A., \& Bukovec, B. (2012). A tool for measurement of innovation newness and adoption in tourism firms. International Journal of Tourism Research, 16(2), 113-125.

Kuokkanen, A., Uusitalo, V., \& Koistinen, K. (2018). A framework of disruptive sustainable innovation: an example of finish food system. Technology Analysis \& Strategic Management, 31(3), 1-16.

León-Bravo, V., Moretto, A., Cagliano, R., \& Caniato, F. (2019). Innovation for sustainable development in the food industry: Retro and forward-looking innovation approaches to improve quality and healthiness. Corporate Social Responsibility and Environmental Management, 26(5), 1049-1062.

Lupova, E. F., \& Dotti, N. (2019). Governance of sustainable innovation: Moving beyond the hierarchy-marketnetwork trichotomy? A systematic literature review using the who-how-what framework. Journal of Cleaner Production, 210, 738-748.

Maier, D., Maftei, M., Maier, A., \& Bitan, G. A. (2019). A review of product innovation management literature in the context of organization sustainable development. Amfiteatru Economic, 21(13), 816-829.

Maines, L., Bitencourt, C. C., Faccin, K., \& Iakovleva, T. 
(2019). Sustainability review the role of stakeholders in the context of responsible innovation: A meta-syntesis. Sustainability, 11(6), 1766. https://doi.org/10.3390 /su11061766

Maleka, A., \& Costa, C. (2014). Integrating communities into tourism planning through social innovation. Tourism Planning \& Development, 12(3), 281-299.

Miranda Torrez, J. (2015). El Modelo de las Capacidades Dinámicas en las Organizaciones. Investigación Administrativa, 44(116), 81-93.

Mousavi, S., Bossink, B., \& Vliet, M. (2018). Dynamic capabilities and organizational routines for managing innovation towards sustainability. Journal of Cleaner Production, 203, 224-239.

Mousavi, S., Bossink, B., \& Vliet, M. (2019). Microfundations of companies' dynamic capabilities for environmentally sustainable innovation: Case study insights from hightech innovation in science-based companies. Business Strategy and the Environment, 28(2), 366-387.

Nieves, J. (2014). Relaciones sociales, capacidades dinámicas e innovación: un análisis empírico en la industria hotelera. Revista Europea de Dirección y Economía de la Empresa, 23(4), 166-174.

OECD. (2009). Sustainable manufacturing and eco-innovation: Framework practices and measurement syntesis report.

OECD. (2011). Fostering innovation to address social challenges.

OECD (2O2Oa). OECD tourism trends and policies 2020.

OECD (2020b). Tourism policy responses to the coronavirus (COVID-19).

Olaya Dávila, A. (2008). Economía de la innovación y del cambio tecnológico: una aproximación teórica desde el pensamiento Schumpeteriano. Revista Ciencias Estratégicas, 16(20), 237-246.

Pace, L. A. (2016). How do tourism firms innovate for sustainable energy consumption? A capabilities perspective on the adoption of energy efficiency in tourism accommodation establishments. Journal of Cleaner Production, 111, 409-420.

Pellegrini, C., Annunziata, E., Rizzi, F., \& Frey, M. (2019). The role of networks and sustainable intrapreneurship as interactive drivers catalyzing the adoption of sustainable innovation. Corporate Social Responsibility and Environmental Management, 26(5), 1026-1048.

Peiró-Signes, A., Segarra-Oña, M., Miret-Pastor, L., \& Verma, R. (2011). Eco-innovation attitude and industry's technological level. Environmental Engineering and Management Journal, 10(12), 1893-1901.
Quandt, C., Ferraresi, A., Kudlawicz, C., Martins, J., \& Machado, A. (2017). Social innovation practices in the regional tourism industry: Case study of a cooperative in Brazil. Social Enterprise Journal, 13(1), 78-94.

Ratten, V., Ramírez, M., \& Lundberg, H. (2020). Managing sustainable innovation. Routledge.

Rhodes, J., Bergstrom, B., Lok, P., \& Cheng, V. (2014). A framework for stakeholder engagement and sustainable development in MNCS. Journal of Global Responsibility, 5(1), 82-103.

Rotondo, F., Corsi, K., \& Giovanelli, L. (2019). The social side of sustainable business model: An explorative analysis of the low-cost airline industry. Journal of Cleaner Production, 225, 806-819.

Schaltegger, S., \& Wagner, M. (2011). Sustainable entrepreneurship and sustainability innovation: Categories and interactions. Business Strategy and the Environment, 2o(4), 222-237.

Schaltegger, S., Hansen, E. G., \& Lüdeke-Freund, F. (2015). Business models for sustainability: Origins, present research and future avenues. Organization \& Environment, 29(1), 3-10.

Schumpeter, J. A. (1934). The theory of economic development: An inquiry into profits, capital, credit, interest, and the business cycle. Oxford University Press.

Schumpeter, J. A. (1968). Capitalismo, sociedad y democracia. ORBIS.

Shang, H., Chen, R., \& Li, Z. (2019). Dynamic sustainability capabilities and corporate sustainability performance: The mediating effect of resource management capabilities. Sustainable Development, 28(4), 595-612.

Sirirat, S. L., \& Lamin, K. S. (2019). Linking corporate sustainability and innovation in supply chain management - Evidence of a Taiwan leading glass recycling company. Technology Analysis \& Strategic Management, 31(8), 957971.

Sobrido, M., \& Rumbo-Prieto, J. M. (2018). La revisión sistemática: pluralidad de enfoques y metodología. Enfermería clínica, 28(6), 387-393.

Szekely, F., \& Strebel, H. (2013). Incremental, radical and game-changing: Strategic innovation for sustainability. Corporate Governance, 13(5), 467-448.

Teece, D. J. (2010). Business models, business strategy and innovation. Long Range Planning, 43(2-3), 172-194.

Teece, D. J. (2012). Dynamic capabilities routines versus entrepreneurial action. Journal of Management Studies, 49(8), 1395-1401.

Teece, D. J. (2018). Business models and dynamic capabilities. Long Range Planning, 51(1), 40-49. 
Templier, M., \& Paré, G. (2015). A framework for guiding and evaluating literature reviews. Communications of the Association for Information Systems, 37(6), 112-137.

Tseng, C.-H., Chang, K.-H., \& Chen, H.-W. (2019). Strategic orientation, environmental innovation capability, and environmental sustainability performance: The case of Taiwanese suppliers. Sustainability, 11(4), 1127. https://doi .org/10.3390/su11041127

United Nations. (2015). Transforming our world: The 2030 Agenda for Sustainable Development. https://sdgs.un.org /2030agenda

Van, L. N. (2019). Sustainable innovation: Pushing the boundaries of traditional operations management. Production and Operations Management, 28(12), 2930-2945.

Vargas Martínez, E. E., Bahena Álvarez, I. L., \& Cordón Pozo, E. (2018). Innovación responsable: nueva estrategia para el emprendimiento de MiPymes. Innovar, 28(69), 41-53.

Vega Jurado, J. (2017). Innovación social. Consejo Nacional de Ciencia y Tecnología.

Velázquez Castro, J. A., \& Vargas Martínez, E. E. (2014). Ecoinnovación en turismo: una aproximación al estado de la cuestión. Gestión y Ambiente, 17(1), 191-207.

Velázquez Castro, J. A., \& Vargas Martínez, E. E. (2015). De la innovación a la ecoinnovación: gestión de servicios en cadenas hoteleras. Revista Venezolana de gerencia, $20(70), 268-281$.
Vinci, G., D’Ascenzo, F., Esposito, A., Musarra, M., Rapa, M., \& Rocchi, A. (2019). A sustainable innovation in the Italian glass production: LCA and Eco Care matrix evaluation. Journal of Cleaner Production, 223, 587-594.

Vos, M. A., Raassens, N., Van der Borgh, M., \& Nijssen, E. J. (2018). Balancing modularity and solution space freedom: effects on organizational learning and sustainable innovation. International Journal of Production Research, 56(20), 6658-6677.

Wagner, M. (2012). Ventures for the public good and entrepreneurial intentions: An empirical analysis of sustainability orientation as a determining factor. Journal of Small Business and Entrepreneurship, 25(4), 519-531.

Yang, M., Evans, S., Vladimirova, D., \& Rana, P. (2017). Value uncaptured perspective for sustainable business model innovation. Journal of Cleaner Production, 140, 17941804 .

Zuñiga-Collazos, A., Castillo-Palacio, M., Pastas-Medina, H. A., \& Andrade-Barrero, M. (2019). Influencia de la innovación de productos en el desempeño organizacional. Revista Venezolana de gerencia, 24(85), 181-198. 